\title{
Josina: collateral damage in a forgotten war
}

Tn 1983 Mozambique is torn by interInal conflict supported by an apartheid South Africa, itself threatened by the existence of this black socialist nation on its flank. Maputo Central Hospital is the country's most important medical centre.

February is the hottest month. On this night the obstetrical team is cleaning up between cases. I'm drinking tea when I get a call from Boris, the Ukrainian surgeon in emergency. Speaking Portuguese, he tells me that a young woman has come in with uterine infection after childbirth. "She's critical." His team is overwhelmed with survivors from a bus that was ambushed on the coast road. "Will you see her soon?"

"As soon as possible," I tell him.

My immediate problem is a woman with a ruptured uterus. It's not an easy operation, and half-way through the city's electrical supply cuts out. The nursing auxiliary flicks on a hand torch and I proceed cautiously by its light for the ten minutes it takes someone to start the hospital's diesel generator. We assume that yet another pylon has been dynamited by os bandidos, as we call the guerillas.

It's 2 a.m. when I break free for the five-minute walk across the hospital compound. The night is silent except for the generator's thunk. The city is dark. There is no moon, and the stars are brilliant in the black sky.

The emergency ward is never a cheerful place, but tonight it is purgatorial. Heat hits me as I enter, and with it the stench of sweat and stale urine. Dim emergency lights glow in the ceiling. There are portable battery-powered lamps by three of the 20 beds.

It's easy to pick her out in the glare of one of them. Thin, very pale, very young, partly covered by a sheet, breathing rapidly. An i.v. line runs to reach arm. A urine tube and bag hang from the bed frame.

Emilia, the medical student with her, seems barely older than her patient. She wears wirerimmed glasses, a T-shirt, jeans, running shoes and a white lab coat soaked with sweat across her back.

She hands me the chart and tells me that Josina is sixteen and gave birth, with her mother's help, to a healthy baby girl a week ago in Maputo's sprawling western fringe. She became feverish three days later and today became confused. Her mother brought her in on a mattress on a flatbed truck. The mother couldn't stay, with four younger children and Josina's baby home alone and the driver keen to go because of danger after dark.

I read Emilia's work-up in the chart. Her presumptive diagnosis, metrite puerperal, gives me a moment's satisfaction. I'd lectured on the topic to her class a month earlier.

Josina is indeed confused. I introduce myself and ask how she feels. Emilia translates from Portuguese to Shangaan. Josina answers in Shangaan, which Emilia interprets for me. "I want to see my baby!"

Josina tries to sit up, then falls back and takes my hand in both of hers and locks her eyes on mine. She says it again. I press her hands between mine and say "You will!" with great conviction. I feel the fever in her moist hands and her quick pulse. Emilia translates, echoing my conviction.

That's all the history we can get and all we need. The uterus, visibly distending her thin abdominal wall, is large, soft and acutely sensitive to touch.

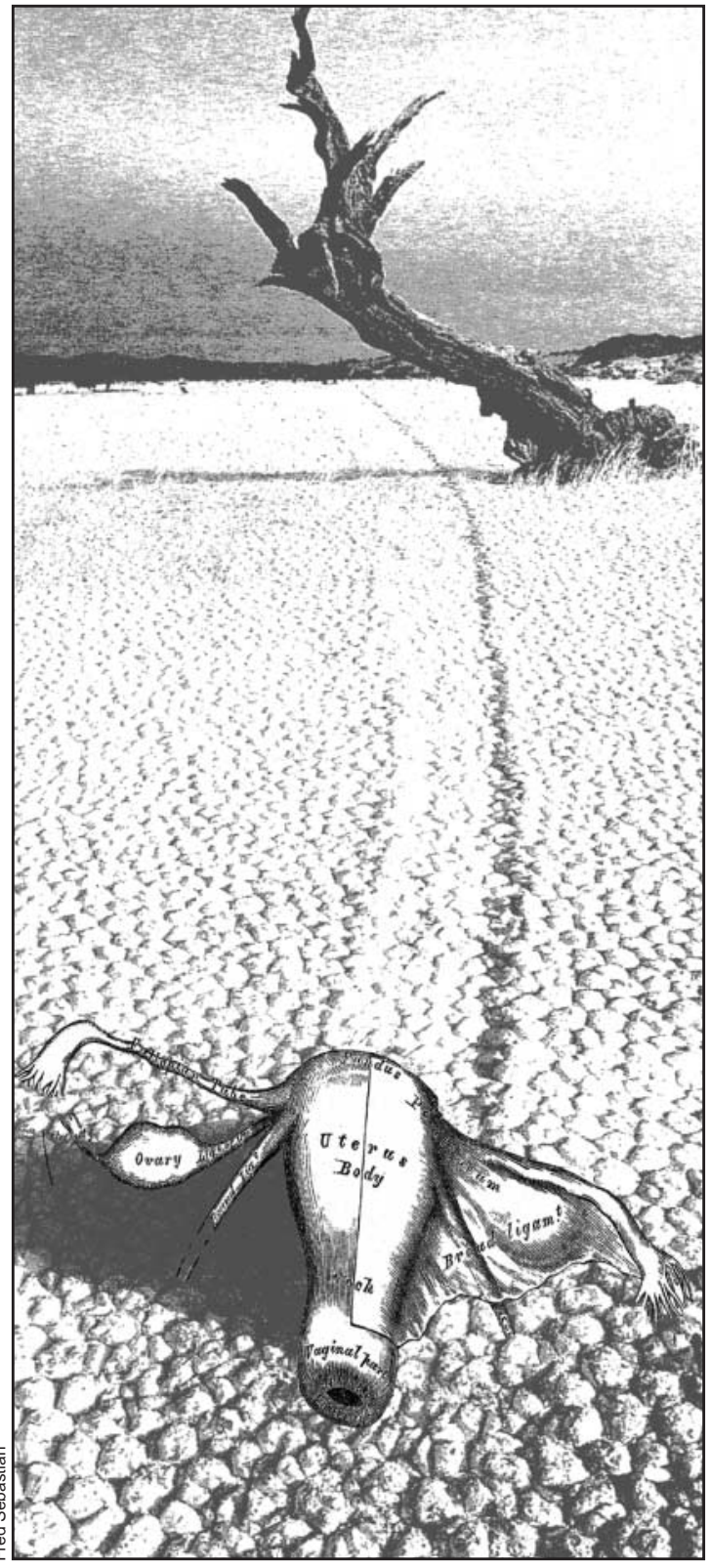

That, and the pus soaking her vaginal pads, leaves no doubt that Emilia and Boris have got it right.

Ideally I should give her my full attention, boost her antibiotic load, rapidly stabilize her circulation with fluids and packed blood cells, and remove her uterus, by now a necrotic sack. I judge that her chance of surviving the procedure is not good, but her 
chance without it is nil. She's at the edge of septic shock.

But life is not ideal. I've got two patients waiting in pain and fear, one with eclampsia, the other with obstructed labour. Each carries a fetus. Four lives. All of whom are likely to survive if attended to soon.

I change some of Boris's orders, add my own and discuss them with Emilia. After her diagnosis I add com peritonite geralizasa and sign the chart.

With Emilia translating, I explain to Josina that she is very sick and will be moved to another part of the hospital for blood transfusions and new treatments. Her womb is infected and should be removed surgically. Does she understand? She grasps my hand again and says "I want to see my baby!" in Shangaan, staring at me. I wonder what she sees. I wonder what she is thinking.

I give Emilia the chart and ask her to see that Josina gets to an isolation room in the maternity ward. She says, "This place is insane. I'll take her there myself." She agrees to stay with her, and to try to explain what is happening.

Back in the theatre a woman is already on the table, prepped and draped. I gulp tea and snatch a mouthful of bread and cheese. Still chewing, I scrub while she is being anesthetized. It's one of those nights at Maputo Central Hospital not routine, but not unusual either.

Much later, I tape down the dressing on my last case and gratefully pull off gloves, mask, cap and gown, wet with sweat. I stretch, thank the scrub nurse and anesthetist, and, sensing cool air, find an open window. I'm surprised to see the sky pale with dawn. Focused on surgery, it's easy to forget that the earth still turns.

Then yet another women with obstructed labour is rolled in. And then Paulo, a Mozambican resident, my relief, my liberator, arrives. He is early, as always.

We sit down with a pot of tea and I tell him about our problem. Josina.
With daylight, travel in the city will be safe. Another team will be in soon to open our second theatre. I intend to preempt their elective list to do Josina first, leaving him free to deal with the incoming.

Paulo smiles sadly and shakes his head. "Não ha problema." Emilia caught him as he came in and took him to her. "She died a half-hour ago. I signed her out. You can go home."

\section{George Povey}

Department of Health Care and

Epidemiology

University of British Columbia

Vancouver, BC

The author taught obstetrics and gynecology as a CUSO cooperant in the Faculty of Medicine, Maputo,

Mozambique, from 1978 though 1992. He now teaches international health at the University of British Columbia.

\section{Night shift}

Everything seemed backward to me when I started working night shifts: it was dark, and I was awake. I looked upon it as if I were the captain of a ship, ferrying patients from night to light, keeping them safe from the storms of pain and anguish. I trawled up and down the halls while bells rang from the beds of the dying. The keys were heavy in my hands; they pulled the pocket of my uniform down; back and forth I went, dispensing mercy in every conceivable form - syringe or solution, tablet or pill, capsule or gellule or infusion or driver. Oh, I would make it all go away. As I walked the halls it was the wail of a concertina I heard each night. Delirium rose with the darkness. Overbed tables were upturned, patients wandered naked in the hallway, incontinent, crying, dying. The fear was palpable, and I had to make it all better, make it go away, soothe it. Me? A regular person nothing special except that I was there when they took their last breath. I would love them and bag them and tag them and ship them down to the morgue on a gurney and think of their souls. And it still stays with me: I remember the names. Sometimes I get a letter from the family. "Thank you," they say. "Thank you for helping us." But I didn't, really; I just did what called me.

So I did this night shift thing for a year, until my brain was fried from lack of sleep. I had to medicate myself to sleep during the day, and it never worked. Invariably the others would find me on a Friday morning in tears, sometimes with the shreds of a dead one on my uniform. Oh yeah, sure, it's just a shell we're in, you say, sure ... but who cleans it up when it springs a leak? I did. And with a smile. And gently, ever so gently. You wouldn't get a rough touch out of me. Even when they were dead, I put music on for their soul to go to heaven, so they could filter up easily to the sky. I wouldn't want them to have a rough ride of it all, even though they had called me 31 times in one night and I had walked myself back and forth and given them oceans t of narcotics. Be gentle, be kind. And really, we all ought to be doing this for the living, though we forget on a daily basis. So I have this question. Who is going to be my gentle angel? Who is going to hold me? Who is my soft spot? Whose wings will I fall under?

Karen Kelly Robson

Palliative Care Nurse

§ Montréal, Que. 